\title{
Results of Testing Maize Hybrids on Lands Shifting from Rice-Growing Areas of Less Efficiency in the Mekong Delta
}

\author{
Le Quy Kha \\ Institute of Agricultural Sciences for Southern Vietnam, 121 Nguyen Binh Khiem Street, District 1, Ho Chi Minh City, Vietnam
}

\begin{abstract}
Forecasters predict that by 2020 there will be 4.5 or 5 million tons per annum maize supply deficiency in Vietnam. As a result of this projection, the government responded by shifting 80,000 ha of low-efficiency rice production areas into maize production (2014-2015) and this area of production for maize is expected to increase to 150,000 ha by 2016-2020. Nevertheless, not all commercial maize hybrids could be suitable for rice-growing land in the Mekong Delta and a national project of hybrid maize development for Mekong Delta has been conducted since early 2014. In the project, yield trials of 20 maize hybrids, sourced from Vietnamese institutions and the private sector including Syngenta (NK67) and Dekalb (DK9901), were sown in Dong Thap, Hau Giang and Long An provinces situated in the Mekong Delta, in minor acid sulphate soils with a pH of 5.0-5.5. The trial included three replications in an Alpha lattice design conducted during spring-summer in 2014. The hybrids flowered at 50-52 d after planting and physiologically matured between 93-97 d after planting. This suggested they would be suitable for cropping systems, which was comprised of three seasons per year. To determine which hybrid is best suited for the region, researchers evaluated yield and ear characteristics. The average yield of the genotypes across locations was 52.03, 54.92 and 57.60 quintals/ha, respectively, and the heritability of genotypes in each location was $0.51,0.81$ and 0.61 , respectively. The mean yield of DK9901 was 58.19 quintals/ha, ranking the 7th among 20 hybrids, and NK67 was 47.58 quintals/ha, ranking the 19th. The grand mean was 54.92 quintals/ha and heritability for all genotypes was 0.79 . The highest yield was produced by the Southern seed company hybrid SSC474 (69.39 quintals/ha), which yielded significantly more maize than DK9901 (58.19 quintals/ha) at $P<0.05$, followed by VS71 from National Maize Research Institute (NMRI) at 63.52 quintals/ha, and LCH9A from NMRI at 63.39 quintals/ha. Although the yield of the VS71 hybrid was greater than the DK9901 hybrid, the ear characteristics were less desirable. Therefore, after comparing these hybrids, it was concluded that SSC474 and LCH9A were the two most suitable hybrids to produce in the Mekong Delta.
\end{abstract}

Key words: Maize (Zea mays L.), hybrid, Mekong Delta, rice-growing land, yield trials.

\section{Introduction}

In recent years, Vietnam has increasingly imported maize for animal feed due to insufficient domestic production. This gap is becoming bigger and bigger. In 2014, according to data by e-finance of Vietnam (2014) [1], the volume of imported maize has move up over 4.794 million tons, at value of over 1.224 million USD, increased by $119.05 \%$ for quantity and 81.4\% for value, compared to the same period of 2013. As data by USDA (2015) [2], post estimates for Vietnam corn imported volume in management year

Corresponding author: Le Quy Kha, Ph.D., research fields: maize breeding and agronomy. E-mail: lquykha@gmail.com.
2014/2015 was 2.0 million tons, down from the 2.4 million tons of management year 2013/2014 due to the expected increase of local production. The above difference between Vietnam e-finance and USDA data is resulted from that Vietnam shipped local corn for selling through the border to China because of the price difference. Therefore, it makes Vietnam become also a seasonal corn exporter in the last decades [2].

As plan of the Ministry of Agriculture and Rural Development of Vietnam [3], they are planning to shift 80 thousands ha of maize from rice-growing land having low efficiency and it will reach to 150 thousands ha of maize on this kind of land by 2020 . Growing maize on rice land has been practiced by 
farmers with positive results. However, in the rice-growing land, autumn-winter rice is the main crop due to favorable sunshine, temperature and irrigation which resulted in always high yield. It means that farmers in this region can grow three crops per year, but they do not want to shift autumn-winter rice land into autumn-winter maize, except some regions are difficult to irrigate rice. Only summer-spring or autumn-summer rice on the deficient water land can be replaced with maize [4]. On the other hand, due to high humidity and warm climate, maize in summer-spring or autumn-summer crops are so far usually susceptible to leaf diseases, such as banded leaf spot blight (Rhizoctonia solani) and rust (Pucinia maydis), stalk rot (Fussarium) and ear rot (Gibberella fujikuroi, Gibberella saubinetii, Gibberella zeae, Fusarium cerealis and Fusarium graminearum), while some maize hybrids are randomly suitable for the region. Thus, farmers in the Mekong Delta are difficult to choose suitable maize hybrids among many common hybrids from multi and domestic companies available in the region. Therefore, in order to achieve the target of the plan in shifting rice production land with low yields into maize cultivation in this region, the selection of maize hybrids suitable for cropping systems of three seasons per year and the efficiently technical package applicable by farmers should be quickly concluded. Contributing to the above objective, a set of new maize hybrids were tested across in Dong Thap (alluvial soil), Hau Giang (high water table soil) and Long An (acrisols) provinces situated in the Mekong Delta, in minor acid sulphate soils with a $\mathrm{pH}$ of 5.0-5.5, with the purpose of selecting the most suitable maize hybrids across locations in the Mekong River region of Vietnam.

\section{Materials and Methods}

\subsection{Materials}

Yield trials of 20 maize hybrids from Vietnamese institutions, such as Northern Seed Company (NSC), Southern Seed Company (SSC), National Maize
Research Institute (NMRI) and checks from Syngenta (NK67) and Dekalb companies (DK9901), were sown in the above mentioned provinces, representing Mekong Delta with minor acid sulphate of pH 5.0-5.5.

\subsection{Methods and Data Analysis}

The experimental design with three replications, 10 maize hybrids in each block of a replication including two blocks was according to Alpha lattice design (incomplete block), in spring-summer season, 2014. Each hybrid was sown in a plot having four rows of $5 \mathrm{~m}$ length, $0.6 \mathrm{~m}$ width and plant to plant distance of $0.2 \mathrm{~m}$. Agronomic traits and cultural techniques were applied by guideline of CIMMYT [5, $6]$.

Data on agronomic traits and yield were analyzed by using excel and IRRISTAT 5.0 software. Heritability was calculated by Eq. (1) [7]:

$$
H=\frac{\sigma_{G}^{2}}{\sigma_{G}^{2}+\left(\sigma_{e / r}^{2}\right)}
$$

where, $H$ is the broad-sense heritability; $\sigma_{G}^{2}$ represents variance due to genotype, which equals to mean square of a genotype (MSG) in a location; $\sigma_{e / r}^{2}$ represents variance due to the environment per replication.

\section{Results and Discussion}

\subsection{Growth Duration}

With a view to selection of promising maize hybrids, which produce high grain yields, can be tolerant to water logging and have good score of plant as well as ear aspect on the rice-growing land in Mekong River Delta, based on data collected, five among 20 tested maize hybrids were chosen for reporting in this paper (Table 1). Data presented in Table 1 showed that all hybrids had tasseled at 50-53 $\mathrm{d}$, silked at 51-54 $\mathrm{d}$ and physiologically matured at 93-97 d after sowing depending on different provinces. With requirement of short growth duration of maize hybrids ( $<100 \mathrm{~d}$ ) suitable for three cropping pattern in 
Mekong region, these hybrids are suitable for three crops per year.

\subsection{Ability of Promising Maize Hybrids Tolerant to Abiotic and Biotic Stresses in Mekong Delta}

Suitable maize hybrids for rice specializing area should have stiff stalk, long stay green leaves, lodging resistance, without dead plants after grain filling stages (green death) and less ear rot percentage, because rainfall is heavy during harvest. Among five selected hybrids (Table 2), DK9901 (check) showed many good characteristics in Mekong Delta, such as less banded leaf spot blight (BLSB) (sore of 1.7), low rate of stem borer (5\%), long stay green leaf (score of 2.3), less root lodging (2.9\%), less rate of green dead plant (7.2\%) and low rate of ear rot (1.9\%). The rate of rotten ears and root lodging of SSC474 (0.7\% and 1.4\%, respectively) and LCH9A (1.3\% and 5.0\%, respectively) were similar to those of DK9901 (1.9\% and 2.9\%, respectively). Green dead rate of LCH9A (15.7\%) was a bit higher than that of DK9901 (7.2\%), but still lower than that of NK67 (41\%). VS71 showed similar score of BLSB to that of DK9901 (score of 1.7). However, its percentage of stem borer and rotten ears were the highest, at $21 \%$ and $7.3 \%$, respectively.

Table 3 showed that SSC474 had got good plant aspect (score of 1.7), good ear aspect (score of 1.0) and tight husk cover (score of 1.7). Similarly, LCH9A had good plant and ear aspect (score of 2.0) and very

Table 1 Growth duration of selected maize hybrids in Hau Giang, Dong Thap and Long An, in spring-summer season, 2014.

\begin{tabular}{|c|c|c|c|c|c|c|c|c|c|}
\hline \multirow{2}{*}{ Hybrids } & \multicolumn{3}{|c|}{ Days to tassel } & \multicolumn{3}{|c|}{ Days to silk } & \multicolumn{3}{|c|}{ Days to physiologically mature } \\
\hline & Hau Giang & Dong Thap & Long An & Hau Giang & Dong Thap & Long An & Hau Gang & Dong Thap & Long An \\
\hline SSC474 (SSC) & 51 & 51 & 49 & 53 & 53 & 51 & 94 & 94 & 95 \\
\hline VS71 (NMRI) & 53 & 52 & 50 & 55 & 54 & 52 & 97 & 95 & 96 \\
\hline LCH9A (NMRI) & 52 & 50 & 49 & 53 & 52 & 52 & 93 & 94 & 95 \\
\hline DK9901 (Dekalb) & 52 & 52 & 51 & 54 & 53 & 53 & 95 & 94 & 95 \\
\hline NK67 (Syngenta) & 52 & 52 & 51 & 54 & 54 & 53 & 96 & 94 & 96 \\
\hline $\begin{array}{l}\text { Grand mean over } \\
20 \text { hybrids }\end{array}$ & 52.1 & 51.1 & 50.2 & 54.0 & 52.8 & 51.3 & 95.9 & 94.0 & 95.0 \\
\hline
\end{tabular}

Table 2 Ability of promising maize hybrids tolerant to abiotic and biotic stresses in three provinces in Mekong River Delta, spring-summer season, 2014.

\begin{tabular}{lllllll}
\hline Hybrids & $\begin{array}{l}\text { BLSB 20 d } \\
\text { after tassel } \\
(1-5)\end{array}$ & $\begin{array}{l}\text { Stem borer 20 d } \\
\text { after tassel } \\
(\%)\end{array}$ & $\begin{array}{l}\text { Stay green } \\
\text { leaf } \\
(1-5)\end{array}$ & $\begin{array}{l}\text { Root lodging at } \\
\text { mature } \\
(\%)\end{array}$ & $\begin{array}{l}\text { Green death at } \\
\text { mature } \\
(\%)\end{array}$ & $\begin{array}{l}\text { Rotten ears } \\
(\%)\end{array}$ \\
\hline SSC474 (SSC) & 2.0 & 7.0 & 3.3 & 1.4 & 7.7 & 0.7 \\
VS71 (NMRI) & 1.7 & 21.0 & 2.3 & 3.3 & 6.1 & 7.3 \\
LCH9A (NMRI) & 2.7 & 10.3 & 2.3 & 5.0 & 15.7 & 1.3 \\
NK67 (Syngenta) & 4.0 & 15.2 & 2.5 & 6.4 & 41.0 & 2.9 \\
DK9901 (Dekalb) & 1.7 & 5.0 & 2.3 & 2.9 & 7.2 & 1.9 \\
\hline
\end{tabular}

Scores 1-5: 1 is best and 5 is worst. The values are average data over three locations of trials.

Table 3 Characteristics of plant and ear of selected maize hybrids over three provinces in Mekong River Delta, spring-summer 2014.

\begin{tabular}{llll}
\hline Hybrids & Plant aspect (1-5) & Ear aspect (1-5) & Husk cover (1-5) \\
\hline SSC474 (SSC) & 1.7 & 1.0 & 1.7 \\
VS71 (NMRI) & 2.3 & 2.7 & 2.7 \\
LCH9A (NMRI) & 2.0 & 2.0 & 1.0 \\
NK67 (Syngenta) & 3.0 & 1.7 & 2.0 \\
DK9901 (Dekalb) & 2.0 & 2.0 & 2.0 \\
\hline
\end{tabular}

Scores 1-5: 1 is best and 5 is worst. The values are average data over three locations of trials. 
tight husk cover (score of 1.0). NK67 had high score of plant aspect (3.0), meaning plant shape does not look good but still had good ear aspect and tight husk cover (score of 1.7 and 2.0, respectively). VS71 had acceptable plant score (2.7), but bad ear aspect and husk cover (2.7). These are resulted from silk worm damage on tip of ear, and then almost $100 \%$ of ear were rotten on tips.

\subsection{Grain Yields of Selected Maize Hybrids in Three Provinces in Mekong River Delta}

Grand mean of 20 maize hybrids in each trial in spring-summer 2014 varies from 52.05 quintal/ha (Dong Thap province) to 57.60 quintal/ha (Long An province). Grand mean of 20 maize hybrids across three locations was 54.92 quintal/ha, with heritability of 0.79 for all genotypes (Table 4). This indicated that the difference among hybrids across location was correct. This also means that yields of all maize hybrids over locations were stable. In Hau Giang province (shallow water table soil) and Long An province (acrisols soil) had high value of heritability of 0.81 and 0.61, respectively. However, in Dong Thap province (alluvial soil) got only 0.51, meaning that variance of yield of hybrids across replications for this trial was larger than that in Hau Giang and Long An province. SSC474 produced the highest yield, raking the 1st among 20 hybrids in both Dong Thap province (66.7 quintal/ha) and Hau Giang province (76.4 quintal/ha), significantly higher than that of DK9901 $(P<0.05)$, ranked the 1st in Long An province (72.8 quintal/ha) $(P>0.05)$ and ranked the 1st over three locations (69.39 quintal/ha). LCH9A got the yield at the 2nd rank in both Dong Thap (65.13 quintal/ha) and Long An provinces (68.8 quintal/ha), those were significantly higher than that of DK9901 but ranked the 5th in Hau Giang province (61.0 quintal/ha). Across three provinces, LCH9A produced average yield of 63.39 quintal/ha and ranked the 3rd among 20 hybrids (Table 4).

Among 20 maize hybrids across three locations in three provinces, VS71 produced the yield at the 2nd rank across three locations (63.52 quintal/ha), but it had bad ear aspect and poor husk cover (2.7) due to damage by silk worm on almost $100 \%$ of ear. Yield of SSC474 ranked the 1st (69.39 quintal/ha), had good plant aspect (smallest score of 1.7), best ear score (1.0) and tight husk cover (score of 1.7). Yield of LCH9A ranked the 3rd, had good plant aspect (score of 2.0), good ear aspect (score of 2.0) and tight husk cover (score of 1.0). In comparison, check NK67 and DK9901 had plant aspect score of 3.0 and 2.0, ear aspect score of 1.7 and 2.0, husk cover score of 2.0 and 2.0, respectively. Therefore, LCH9A and the check DK9901 were selected because they have similar plant and ear aspect core (Fig. 1).

Table 4 Grain yields of selected maize hybrids in three provinces in Mekong River Delta, in spring-summer 2014.

\begin{tabular}{|c|c|c|c|c|c|c|c|c|}
\hline \multirow[b]{2}{*}{ Hybrids } & \multicolumn{2}{|c|}{ Dong Thap } & \multicolumn{2}{|c|}{ Hau Giang } & \multicolumn{2}{|c|}{ Long An } & \multicolumn{2}{|c|}{ Mean over three provinces } \\
\hline & $\begin{array}{l}\text { Average } \\
\text { (quintal/ha) }\end{array}$ & $\begin{array}{l}\text { Order in } \\
20 \text { hybrids }\end{array}$ & $\begin{array}{l}\text { Average } \\
\text { (quintal/ha) }\end{array}$ & $\begin{array}{l}\text { Order in } \\
20 \text { hybrids }\end{array}$ & $\begin{array}{l}\text { Average } \\
\text { (quintal/ha) }\end{array}$ & $\begin{array}{l}\text { Order in } \\
20 \text { hybrids }\end{array}$ & $\begin{array}{l}\text { Mean } \\
\text { (quintal/ha) }\end{array}$ & $\begin{array}{l}\text { Order in } \\
20 \text { hybrids }\end{array}$ \\
\hline SSC474 & 66.7 & 1 & 76.4 & 1 & 72.8 & 1 & 69.39 & 1 \\
\hline VS71 & 53.9 & 8 & 66.9 & 2 & 72.4 & 2 & 63.52 & 2 \\
\hline LCH9A & 65.1 & 2 & 61.0 & 5 & 68.8 & 5 & 63.39 & 3 \\
\hline NK67 & 40.7 & 18 & 47.0 & 16 & 58.5 & 19 & 47.58 & 19 \\
\hline DK9901 & 55.1 & 7 & 51.3 & 12 & 69.4 & 4 & 58.19 & 7 \\
\hline $\begin{array}{l}\text { Grand mean of } \\
\text { trial (quintal/ha) }\end{array}$ & 52.05 & & 54.9 & & 57.60 & & 54.92 & \\
\hline $\mathrm{H}$ & 0.51 & & 0.81 & & 0.61 & & 0.79 & \\
\hline CV (\%) & 18.6 & & 11.9 & & 1.63 & & & \\
\hline LSD (0.05) & $16.0^{*}$ & & $10.8^{* *}$ & & 17.0 & & & \\
\hline
\end{tabular}

H: Broad sense heritability; CV: coefficient of variation; LSD: least significant difference; *: significance at probability > 0.05; **: significance at probability $>0.01$. 

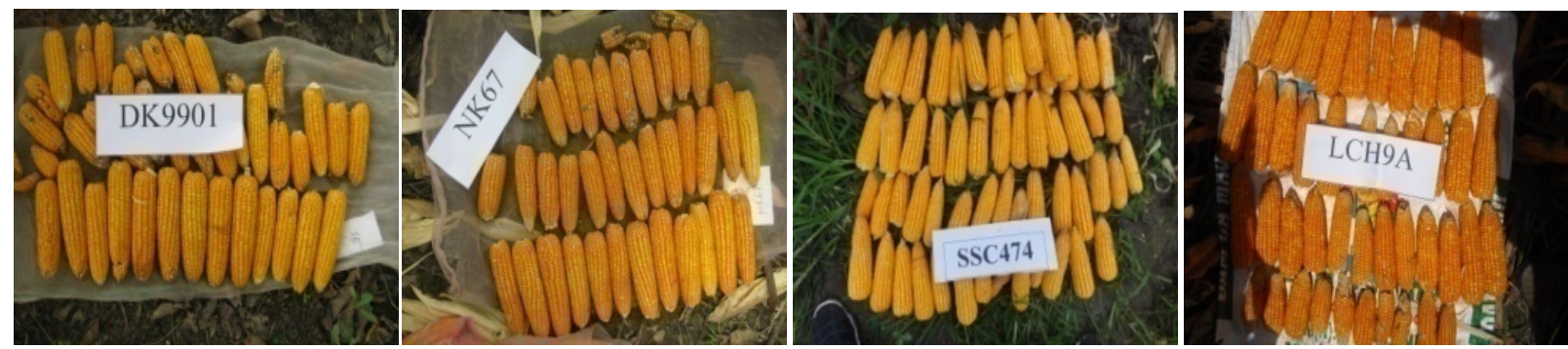

Fig. 1 DK9901 (Dekalb), NK67 (Syngenta) and two new hybrids by Vietnamese institutions in Mekong River Delta, in spring-summer, 2014

\subsection{Discussion}

In the Mekong River Delta of Vietnam, the maize cultivation is of not only the opportunities but also the challenges in comparative advantages with imported maize which has low-trend price in recent years. The survey on 360 households, who shifted rice land to maize cultivation in the provinces of Long An, Dong Thap and Hau Giang, pointed out that the productive efficiency of maize fluctuated highly by the soil types affecting grain yield potential and by the cropping season. The maize hybrid DK888 (Dekalb company) and advanced cultivation package on nutrient management and planting density were demonstrated in Phong Dien district, Can Tho city in spring-summer 2014. Compared to rice cultivation with yield of 5.15 tons/ha, maize applying conventional cultivation produced an average yield of 6.66 tons/ha, bringing benefit of VND 3.237 million/ha, while maize yield in demonstration plots of 40 ha where applied advanced cultivation package was 7.05 tons/ha, bringing benefit of VND 4.518 million/ha [8]. In Dong Thap province, in demonstration of DK9955 in autumn-winter crop on land shifting from rice cultivation, yield of DK9901 was 11.3 tons/ha, while yield of rice was 6.25 tons/ha. Profitability of maize cultivation was VND 10.34 million/ha and that of rice cultivation was VND $4.17 \mathrm{million} / \mathrm{ha}$, making the difference of VND 6.167 million/ha [9]. In the author' trial, yield of DK9901 (shorter growth duration than DK9955, about 7-10 d) varied from 55.1 quintal/ha to 69.4 quintal/ha. The big difference of yield between trials and demonstration, and yield of demonstrations between summer-spring and autumn-winter crops are resulted from: (1) soil fertility and farmers' capacity of input investment in Can Tho province were not equal to those in Dong Thap province; (2) DK9955 is the maize hybrids has longer growth duration (115 d from sowing to physiological maturity) than DK9901 (105 d). This means that in Mekong River Delta, the soil types in terms of fertility, water table, etc., and capacity of farmers investing agro-inputs affect the yield differently. The non-comparative parameters, such as cropping seasons, soil types and fertilizer investment, are critical to compare the effectiveness of a new maize hybrids in the Mekong River Delta of South Vietnam.

\section{Conclusions and Recommendations}

Compared to the check hybrid DK9901 (Dekalb Vietnam Ltd. Company) which is popular nationwide in Vietnam, two maize hybrids developed by Vietnamese institutions having medium growth duration (95 d) are suitable for three cropping system in Mekong River Delta. Yield of SSC474 was the highest and LCH9A was the 3rd among 20 tested hybrids. They have good plant aspect (score of 1.7 , 2.0, respectively), good ear aspect (score of 1.0, 2.0, respectively) and tight husk cover (score of 1.7, 2.0, respectively).

SSC474 and LCH9A are highly recommended for larger scale-demonstration for field day tours in extension activities in the Mekong River Delta.

\section{References}

[1] Huyen, T. 2015. "Maize Importation in Vietnam Increased by $119.05 \%$ in 2014.” An E-Finance of Vietnam. Accessed January 20, 2015. http://www. 
taichinhdientu.vn/Home/Nam-2014-Nhap-khau-ngo-tang11905/20151/140719.dfis. (in Vietnamese)

[2] Tran, Q., and Wilder, D. 2015. Vietnam 2015 Grain and Feed Annual. Global Agricultural Information Network Report, USDA Foreign Agricultural Service.

[3] Ministry of Agriculture and Rural Development. 2013. "Plan of Shifting Rice-Growing Land Having Lower Economic Efficiency into Maize, Soybean and Other Upland Crops.” Department of Crop Production, Ministry of Agriculture and Rural Development, Vietnam. Accessed July 31, 2014. http://thuvienphapluat.vn/ van-ban/Linh-vuc-khac/Quyet-dinh-3367-QD-BNN-TT-2 014-chuyen-doi-co-cau-cay-trong-lua-2014-2020-242613 .aspx. (in Vietnamese)

[4] Kha, L. Q. 2014. "National Project on Hybrid Development and Technical Package for Maize Production on Land Shifting from Rice-Growing Area.” Ministry of Agriculture and Rural Development of Vietnam. Accessed June 17, 2014. http://iasvn.org/ chuyen-muc/De-tai-cap-bo-000210022003l.html. (in Vietnamese)
[5] International Maize and Wheat Improvement Center (CIMMYT). 1985. Managing Trials and Reporting Data for CIMMYT's International Maize Testing Program. El Batan, Mexico: CIMMYT.

[6] Kha, L. Q. 2013. A Hand Book of Field Trial Management, Data Collection and Understanding Results of Statistical Analysis. Vietnam: Vietnam Science and Technology Publishing House, 41. (in Vietnamese)

[7] Falconer, D. S., and Mackay, T. F. C. 1996. Introduction to Quantitative Genetics, 4th ed.. Essex, England: Longman Publisher.

[8] Khuong, T. Q., and Phuong, L. N. 2014. "Improving Profitability of Maize Production on Low Efficiency Rice-Growing Land in Can Tho Province, Mekong River Delta.” Journal of Vietnam Agricultural Science and Technology 7 (53): 105-10. (in Vietnamese)

[9] Center for Extension in Dong Thap Province. 2014. Report on Results of Demonstration of DK99055 Maize Hybrid on Low Efficiency Rice Production Land. (in Vietnamese) 